\title{
Acercamientos para el abordaje de lo intermedial e interdisciplinario en la cultura argentina
}

\author{
Teatro XXI. Revista del GETEA. Número 36, 2020. Buenos Aires. ISSN 2683-8451
}

\section{(4) Mariana Pensa}

El número 36 de Teatro XXI, Revista del Getea (revista académica dependiente del Instituto de Historia del Arte Argentino y Latinoamericano "Luis Ordaz", de la Facultad de Filosofía y Letras, de la Universidad de Buenos Aires) presenta las ponencias leídas en el Primer Simposio Internacional "Relaciones intermediales e interdisciplinarias en la cultura argentina", organizado el 4 de diciembre de 2018 en la Universidad de Cambridge (Inglaterra) por las profesoras Ana Laura Lusnich (UBA/CONICET) y Joanna Page (Universidad de Cambridge).

El primer artículo, “Cuarto intermedio: una comedia negra (e intermedial) sobre los juicios de lesa humanidad" de Jordana Blejmar, analiza la conferencia performática e intermedial Cuarto intermedio: Guía práctica para los juicios de lesa humanidad, del escritor Félix Bruzzone y la abogada y actriz Mónica Zwaig, estrenada en 2018. El texto funciona con la idea de contagio y contacto entre diferentes campos, trabajando con distintos lenguajes discursivos (el jurídico-teatral, el teatral, el cinematográfico, el derecho humanístico), combinándolos en la hibridez y la ambigüedad para poder, así, representar el horror, y poner en acción los mecanismos de la memoria. La autora refiere a cómo Bruzzone, que es hijo de desaparecidos, no autoficcionaliza su condición de víctima, dejando de lado la primera persona, para poder hablar del pasado desde otros lugares. Al sacar a los juicios de su lugar habitual y armar una imagen de ellos a través del montaje con distintos materiales, lenguajes y discursos, se propone una lectura crítica del pasado, a la vez que se incluye también al futuro.

El segundo artículo, "Intermedialidad: interrupción creativa disidente de la sexopolítica hegemónica en las prácticas artísticas de Effy Beth y Diego Casado Rubio", de Ezequiel Lozano, revisa propuestas del director español Casado Rubio y la artista trans-feminista queer Effy Beth. El autor se detiene en Millones de segundos, una puesta que el primero realiza en el 2017 , en donde se refieren historias de vida, cuyo origen es un video de Youtube. Mediante una tablet que es el centro de la puesta, se produce una articulación de mundos virtuales, reales e imaginarios, al mismo tiempo que los recursos de la puesta siguen al de los youtubers, por ejemplo en la forma de hablar a cámara. Pequeña Elizabeth Mati (Little Mermaid doblado al castellano), de Effy Beth, recurre también a lo digital, en este caso a un VHS, en donde el teatro documental intersecta la narración autobiográfica y el video hogareño. Nacido como una videoperformance en el 2012, y como una edición de diferentes videos personales, los subtítulos en castellano, del original en hebreo, tienen que ver con la autopercepción genérica y el abandono del lenguaje patriarcal.

El tercer artículo, “Remontaje y producción de sentido histórico en las instalaciones audiovisuales y los films recientes de Albertina Carri”, de Ana Laura Lusnich, se detiene en la relación que la cineasta establece con el archivo audiovisual (propio y ajeno) y el patrimonio, así como con su trabajo con el remontaje, la recreación y la confluencia de formatos, con el objetivo de señalar la violencia institucional y promover la producción de memoria a través de las imágenes. Como archivista, Carri recupera el material audiovisual o fotográfico, trabajando con lo que queda de ese material y, al evocarlo, lo presenta, como en el caso de Cuatreros (2016), en donde quiere poder presentar la historia de Isidro Velázquez, en pantalla múltiple. En la instalación Operación fracaso y el sonido recobrado (2015), por otra parte, y a partir de lo multimedial y lo transdisciplinario, se desplaza al cine de la sala tradicional hacia el museo; Carri, según Lusnich, produce así un "cine físico" que excede a la pantalla, explorando, de esta manera, un nuevo campo de producción.

El cuarto artículo, "Ficciones fundacionales argentinas en el teatro porteño contemporáneo", de Lía Noguera, se concentra en la manera en que los discursos canónicos de nuestra literatura son apropiados en el teatro a través de lo intermedial, creando nuevos discursos y paradigmas. La investigadora se detiene en tres obras: Bufarra-carne a la parrilla (2016-2018) de Eugenio Soto, Cosas como si nunca (Beatriz Catani, del 2018) y La vida extraordinaria (Mariano Tenconi Blanco, 2018). La primera obra, que tiene como referentes a El matadero y La refalosa de Ascasubi, traza líneas con la violencia sexual del cuento de Echeverría, transfiriéndola a un 
ambiente hogareño actual. Cosas si nunca, por otro lado, suma elementos del cine, la música y la payada en su puesta, y trabaja sobre la temática de la cautiva, tal como aparece originalmente en La cautiva, Facundo y el Martín Fierro, refuncionalizando al sujeto, haciéndolo contenedor de una historia móvil (la cautiva de este texto ha sido criada en Alemania). El último texto trabaja con el Martín Fierro y, a través de la amistad de las dos protagonistas, resignifica la amistad de Fierro con el sargento Cruz. Cine y música potencian tanto lo textual como lo escénico en esta obra.

El quinto artículo, “Catástrofe y utopía en el teatro de Rafael Spregelburd. Lectura de un paisaje intermedial", de María Fernanda Pinta, es un acercamiento a la obra Spam (2013), concentrándose

en su calidad de texto que pone en juego diferentes obras y sistemas (como los de la literatura, el cine y la pintura) al hacer uso del archivo cultural y social (a partir de las alusiones del texto a, por ejemplo, James Bond, Caravaggio y El extranjero de Camus). Mario Monti, el protagonista, es un hombre con amnesia que se encuentra en un cuarto de hotel, y que va realizando un trabajo detectivesco y de reciclaje, a través de los spams, para poder desentrañar quién es. Si esos mensajes del exterior no le dan muchos datos, ya que las palabras están mediadas por equívocos e imperfecciónes, al menos, como manifiesta la autora, Mario tiene conexión, tiene Internet. Como texto plurimedial, la puesta deviene en performance sonora, dialogando con otros sistemas, y ayudando a formar un sentido final que revela un retrato complejo del hoy.

El sexto artículo, "Reciclaje: materializaciones de militancia en la ExESMA", de Erika Teichert, se focaliza en las intervenciones artísticas realizadas en el espacio Memoria y Derechos Humanos, estudiando tales manifestaciones a partir de una estética de reciclaje que cruza militancia, arte y derechos humanos. Como espacio permanentemente en construcción, la exESMA no es un museo tradicional, ya que genera vínculos afectivos, señala la autora, a la vez que se instituye en un circulante de iconos e imágenes que se vuelven a repetir, proponiendo, entonces, una continuidad. Esta idea de continuidad se puede apreciar en Presentes del Grupo de Arte Callejero, una intervención con versiones de las fotos de desaparecidos, en donde a medida que el papel se regenera se van erigiendo nuevas imágenes, a las que el grupo va interviniendo una y otra vez, en un acto de militancia. Siguiendo la misma línea, la Instalación Carta Rodolfo Walsh, refleja el espíritu del espacio, al haber sido creada como un acto involuntario, y adjunta a la cual se pueden ver restos de otra intervención.

El último artículo, “Indigenismo imaginado: representaciones incaicas a través de la ópera y el teatro en Argentina en los años 20', de Vera Wolkowicz, estudia las óperas Ollantay de Constantino Gaito y Corimayo de Enrique Mario Casella, ambas de 1926, como formas del uso del imaginario incaico en el teatro nacional. Ambas óperas surgen como parte del boom por lo arqueológico de principios del siglo XX y fueron producidas por la Misión Peruana de Arte Arcaico, dirigida por Luis E. Valcarcel; de hecho, ambas performances tienen un tinte eminentemente arqueológico, un carácter científico, señala la autora, donde se dejan de lado los elementos del teatro tradicional. Ambas óperas, a pesar de sus temáticas y fuentes incaicas se compusieron con música de canon europeo y, en el caso de Ollantay fue cantada en italiano; europeísmo que contrasta con los trajes y escenografías nativistas. La crítica del momento da cuenta de estas contradicciones y juzga a las óperas por su valor "históricoarqueológico", problematizando la idea de promoción de un arte nacional.

La revista se completa con un editorial de Marina Sikora y las tradicionales secciones "Testimonios del pasado teatral argentino", "Teatro en Argentina" y "Lecturas". El "Dossier" incluye la obra Muerde de Francisco Lumerman, con una entrevista al autor realizada por Azucena Ester Joffe.

Con su focalización en los estudios intermediales e interdiciplinarios, los trabajos presentados en este número de Teatro XXI. Revista del GETEA se sitúan en la vanguardia de los mismos, abriendo una necesaria puerta para futuros abordajes de investigación sobre estas perspectivas. 